\title{
Seroprevalence of Bartonella henselae in cats in Germany
}

\author{
M. HAIMERL, A. M. TENTER*, K. SIMON†, M. ROMMEL*†, J. HILGER and I. B. AUTENRIETH \\ Max von Pettenkofer-Institut für Hygiene und Medizinische Mikrobiologie, Ludwig Maximilians-Universität \\ München, Pettenkoferstraße 9a, D-80336 München, *Institut für Parasitologie, Tierärztliche Hochschule \\ Hannover, Bünteweg 17, D-30559 Hannover and †WHO-Centre 'Veterinary Public Health' an der \\ Tierzärztlichen Hochschule Hannover, Bünteweg 2, D-30559 Hannover, Germany
}

\begin{abstract}
Bartonella henselae and $B$. quintana infections in man are associated with various clinical manifestations including cat-scratch disease, bacillary angiomatosis and bacteraemia. While cats are the natural reservoir for $B$. henselae, the source of $B$. quintana is unclear. In this study, the sera of 713 cats from Germany were examined for the presence of antibodies against $B$. henselae, $B$. quintana or Afipia felis by an indirect immunofluorescence assay (IFA). Bartonella-specific antibody titres of $\geqslant 50$ were found in $15.0 \%$ of the cats. There was substantial cross-reactivity among the various Bartonella antigens, although single sera showed high titres against $B$. henselae but not against $B$. quintana and vice versa. Antibodies against $A$. felis were not detected in any of these cats. Statistical analysis indicated that there is no correlation between Bartonella infections and the sex, age or breed of the cat or its hunting behavior. There was also no correlation between bartonella and toxoplasma infections in cats. However, whereas $16.8 \%$ of cats from northern Germany had $B$. quintana-specific antibodies, only $8.0 \%$ of cats from southern Germany were seropositive for $B$. quintana. No statistically significant difference was found for $B$. henselae. IFA-positive and IFA-negative sera were used for immunoblot analysis including $B$. henselae and $B$. quintana. Marked reactivity was observed with protein bands at $80,76,73,65,37,33$ and $15 \mathrm{kDa}$. The results of this study suggest that $B$. henselae, and possibly a $B$. quintana-related pathogen, but not $A$. felis, are common in cats in Germany, and that there are differences in the geographic distribution of bartonella infections in cats.
\end{abstract}

\section{Introduction}

Bartonella species are gram-negative, facultative intracellular bacteria of the $\alpha 2$-Proteobacteria group. At present, 11 Bartonella species are known, five of which - B. henselae, B. quintana, B. elizabethae, $B$. bacilliformis and $B$. clarridgeiae - are pathogenic for man [1-3]. B. bacilliformis is endemic in the Andes region of South America and causes a diphasic illness designated as Carrion's disease, presenting with acute Oroya fever and chronic verruga peruana $[4,5] . B$. quintana and $B$. henselae probably occur world-wide and are associated with a variety of clinical manifestations including cat-scratch disease, bacillary angiomatosis and pelliosis [1-3]. Trench fever, bacteraemia, endocarditis and chronic lymphadenopathy may also be

Received 6 Oct. 1998; revised version accepted 11 Dec. 1998.

Corresponding author: Professor I. B. Autenrieth (e-mail: Autenrieth@m3401.mpk.med.uni-muenchen.de). associated with $B$. henselae or $B$. quintana infections [6-12]. Less frequent clinical manifestations such as lesions in bone tissue, liver, lungs and eyes, as well as various neurological symptoms, have been attributed to bartonella infections [13-20]. More recently, B. clarridgeiae has been associated with cat-scratch disease and septicaemia [21, 22].

Afipia felis has also been associated with cat-scratch disease in man [23, 24]. However, although one study reported a seroreactivity of $5-7 \%$ in 430 human sera with $A$. felis antigen [25], others argued against an important role for this organism in man [26-28].

While cats are clearly recognised as the natural reservoir of $B$. henselae, the reservoirs of $B$. quintana, $B$. bacilliformis and $A$. felis have not yet been identified $[1,3,29,30,31]$. The prevalence of $B$. henselae antibodies in sera of domestic cats in various regions of North America varied between 3.7 and 54.6\%, depending on the temperature and humidity of the 
different regions $[29,32]$. In man, contact with cats or cat fleas, childhood and immunosuppression are epidemiological risk factors for $B$. henselae infections, while HIV infection, homelessness, chronic alcoholism, infestation with lice (Pediculus humanus) and close contact between individuals are risk factors for $B$. quintana infections [7,33-36]. The seroprevalence of bartonella infections in man varies between 1 and $20 \%$ [26-28, 37-39]. A seroprevalence of $12 \%$ was found in healthy blood donors in Germany (Autenrieth et al., unpublished observations).

Two $B$. henselae variants have been demonstrated recently in domestic cats in Germany by $16 \mathrm{~S}$ rRNA sequence analysis, enterobacterial repetitive intergenic consensus (ERIC)-PCR and SDS-PAGE [40]. In 13\% of cats, $B$. henselae could be isolated from the blood [40]. However, the epidemiology of bartonella infections in man or in cats in Germany has not yet been studied and the aim of this study was to determine the seroprevalence of $B$. henselae in comparison with $B$. quintana and $A$. felis in domestic cats in Germany.

\section{Materials and methods}

\section{Sera and animals}

Sera were collected from 713 cats during 1993 and 1994 (Table 1); 200 of these sera were collected at a veterinary clinic in southern Germany (district of Schweinfurt), the other 513 sera were collected at various veterinary practices in northern Germany (Niedersachsen, Hamburg, Bremen, Schleswig-Holstein and Nordrhein-Westfalen). The owners of the 513 cats

Table 1. Epidemiological characteristics of pet cats included in this study*

\begin{tabular}{lc}
\hline Characteristic & Percentage \\
\hline Age & \\
$1-6$ months & 4.5 \\
$7-12$ months & 17.2 \\
$1-2$ years & 15.2 \\
$2-5$ years & 19.1 \\
$6-10$ years & 16.6 \\
>10 years & 10.5 \\
Breed & \\
European short hair & 73.5 \\
Pedigree cats & 16.6 \\
Sex & \\
Male & 52.0 \\
Female & 37.2 \\
Environment & 25.9 \\
Indoor cats & 47.9 \\
Outdoor cats & \\
Hunting behaviour & 37.8 \\
Hunting & 33.3 \\
No hunting & 27.7 \\
T. gondii seroprevalence & 72.3 \\
Positive & \\
Negative & \\
\hline A total of &
\end{tabular}

${ }^{*}$ A total of 713 cats was studied: $200(28.1 \%)$ were from southern Germany and $513(71.9 \%)$ were from northern Germany. The characteristics detailed above are derived only from the cats from northern Germany. from northern Germany were requested to provide the following information: age, breed and sex of the cat, the type of environment and the cat's hunting behaviour (Table 1). The sera had previously been examined for Toxoplasma-specific antibodies and were stored at $-20^{\circ} \mathrm{C}$.

\section{Bacteria}

The following strains of bacteria were used: $B$. henselae (Houston strain) ATCC 49793; B. henselae (Marseille strain; a kind gift from Professor D. Raoult, Marseille, France); a $B$. quintana isolate from a patient in Munich [41] and A. felis ATCC 53690. B. henselae and $B$. quintana were grown at $37^{\circ} \mathrm{C}$ for $8-10$ days on chocolate agar plates containing defibrinated sheep blood $10 \%$ until the colonies reached confluence. Bacteria were harvested by rinsing the plates with phosphate-buffered saline (PBS, pH 7.4). Suspensions of bacteria were washed three times with PBS and then centrifuged for $10 \mathrm{~min}$ at $11950 \mathrm{~g}$. The pellets were suspended in $1 \mathrm{ml}$ of $\mathrm{NaCl} 0.9 \%$ solution containing sodium azide $0.1 \%$ and further diluted to the appropriate concentration and stored at $4^{\circ} \mathrm{C}$. Pili expression of $B$. henselae was confirmed by transmission electron microscopy (data not shown). A. felis was grown on charcoal-yeast extract (BCYE) agar plates at $30^{\circ} \mathrm{C}$ for 5 days, harvested and suspended as described for Bartonella spp.

\section{Cell cultures}

Vero cells (ATCC, Rockville, MD, USA) were grown in tissue-culture flasks (Nunc) in DMEM (Seromed, Germany) supplemented with fetal calf serum (Seromed) $10 \%$, glutamine (Biochrom) $0.1 \%$, sodium pyruvate (Biochrom) $0.1 \%$ and non-essential amino acids (Gibco) $0.1 \%$ at $37^{\circ} \mathrm{C}$ in a humidified atmosphere containing $\mathrm{CO}_{2} 5 \%$. Cells were grown without antibiotics to a density of $c .10^{5}$ cells $/ \mathrm{ml}$. They were infected with $B$. henselae at a bacteria:cell ratio of $c$. 100:1. Infected Vero cells were subcultured every 2-3 weeks and cells from the fourth subculture were harvested. The resulting suspension containing Vero cells and bacteria was washed in PBS, centrifuged and suspended as described above for bacteria harvested from agar plates.

\section{Immunofluorescence assay (IFA)}

The IFA was performed according to standard methods. Antigen preparations as described above (cell culture and conventional agar plate cultures) were applied to glass slides, air-dried and fixed by incubation in methanol for $15 \mathrm{~min}$ at $-20^{\circ} \mathrm{C}$. Serial dilutions of sera starting at 1 in 50 were prepared in PBS containing bovine serum albumin (Biomol) $0.5 \%$ and Tween 20 (Sigma) $0.1 \%$. Antigen slides were overlaid with the serum dilutions and incubated for $30 \mathrm{~min}$ at $37^{\circ} \mathrm{C}$ in a humidified chamber. After washing with the PBS buffer 
described above, FITC-conjugated $\left(\mathrm{F}\left(\mathrm{ab}^{\prime}\right)_{2}\right.$-fragment goat anti-cat IgG $(\mathrm{H}+\mathrm{L})$ (Dianova, Hamburg, Germany) diluted 1 in 100 in PBS buffer containing Evans blue $0.1 \%$ was added to the slides and incubated for $30 \mathrm{~min}$ at $37^{\circ} \mathrm{C}$. After final washing steps, the slides were air-dried, mounted in buffered glycerol (Fluoprep; Merck) and examined by fluorescent microscopy (Leitz Aristoplan, Heidelberg, Germany).

\section{Immunoblot analysis}

Bacterial suspensions of $B$. henselae (Houston, Marseille) were prepared as described above. Bacterial lysates were prepared by heat treatment $\left(100^{\circ} \mathrm{C}\right.$ for $5 \mathrm{~min}$ ), separated on SDS polyacrylamide $12.5 \%$ gels and transferred to nitrocellulose by Western blotting as described previously [42]. After incubation with blocking buffer, nitrocellulose strips were incubated with cat sera diluted 1 in 100 in PBS containing Tween $200.5 \%$ overnight at ambient temperature. They were washed three times with PBS containing Tween $200.5 \%$ and incubated with a 1 in 100 dilution of $F\left(a b^{\prime}\right)_{2}$-fragment goat anti-cat IgG $(\mathrm{H}+\mathrm{L})$ conjugated to alkaline phosphatase (Dianova) for $90 \mathrm{~min}$ at ambient temperature. After final wash steps, the reactions were developed as described elsewhere [42].

\section{Statistical analysis}

Statistical analysis was performed with the computer programme SAS (SAS Institute, Cary, NC, USA). The relationships between the prevalence of antibodies to different bartonella antigens and various parameters that may be of importance for the epidemiology of bartonella infections in cats were examined by Fisher's exact test and the $\chi^{2}$ test.

\section{Results}

A total of 713 sera samples was obtained from German pet cats and serological tests were used to determine the presence of anti-Bartonella IgG antibodies. The IFA results were considered positive when immunofluorescence was clearly noted at a titre of $\geqslant 50$. In immunofluorescence assays, two types of antigens were used: conventional bacterial antigen derived from bacteria grown on agar plates and $B$. henselae grown and harvested in co-culture with Vero cells.

A total of $107(15.0 \%)$ sera gave positive results for Bartonella spp. Of these sera, $40(5.6 \%)$ had antibodies against $B$. henselae (Marseille strain) and $44(6.2 \%)$ against $B$. henselae (Houston strain); 102 (14.3\%) exhibited antibodies against $B$. quintana $(\mathrm{p}<0.01$; Fig. $1)$. There was no significant difference in seroprevalence between the two $B$. henselae antigens (Marseille strain versus Houston strain). The maximum IFA titre detected was 400 (Fig. 2). None of the sera contained antibodies against $A$. felis.

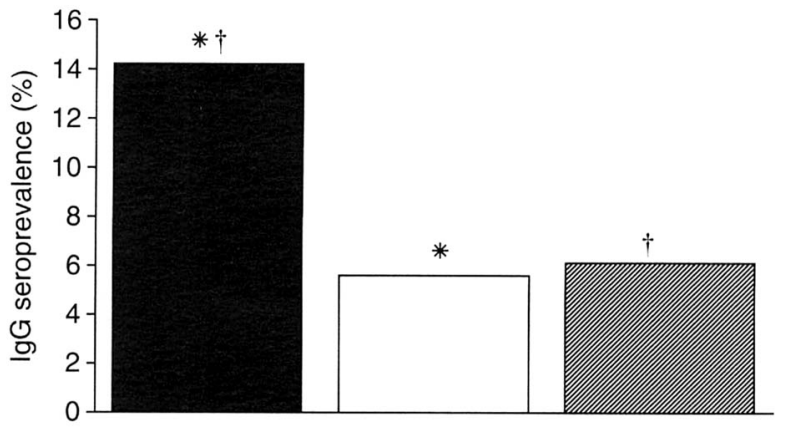

Fig. 1. Prevalence of anti-B. quintana (₫), anti-B. henselae Houston strain $(\square)$ and anti- $B$. henselae Marseille strain (ש) antibodies in sera of 713 German cats as revealed by IFA assay. Sera with a titre $\geqslant 50$ were considered positive. ${ }^{* \dagger} \mathrm{p}<0.01$.

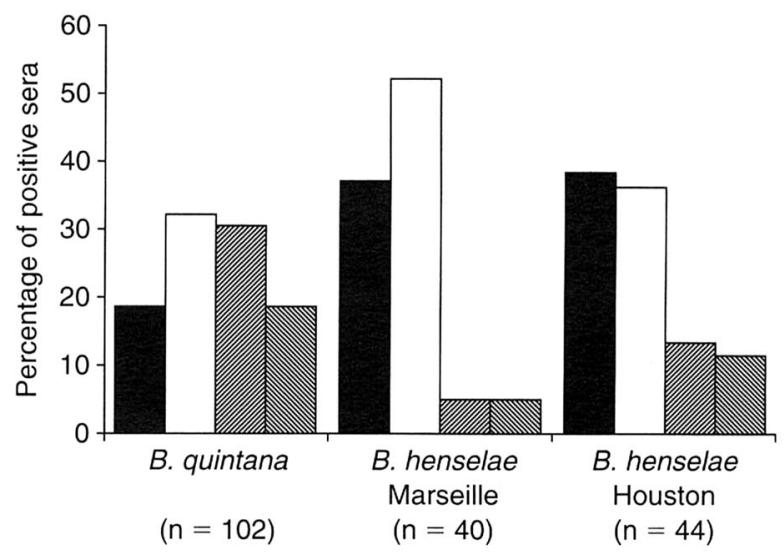

Fig. 2. Bartonella-specific antibody titres of 713 sera from German cats as revealed by IFA including conventionally grown bacteria as an antigen: $\square, 50 ; \square, 100 ; \square$, $200 ; \mathbb{Q}, 400$.

Eighteen IFA-negative and 13 IFA-positive sera were analysed in parallel by an IFA including cell-culture antigen. Comparison of antibody titres of cat sera for these two antigens revealed $46 \%$ higher antibody titres with the cell culture antigen when compared with the conventional antigen (data not shown). However, the sera with negative antibody titres in the conventional IFA did not show positive antibody titres in the IFA with cell-culture antigen.

Details of age, breed, sex, environment, hunting behaviour and $T$. gondii-specific serum antibody prevalence were recorded for 513 cats. None of the cats aged 1-6 months had serum antibodies against $B$. henselae (Table 2). Seroprevalence in 7-12-month-old cats against $B$. henselae was $5.7 \%$ and remained at this level in older cats, suggesting that in most cases seroconversion occurred within the second part of the first year of life. The seroprevalence of anti- $B$. quintana antibodies was higher than that of $B$. henselae antibodies. Thus, $13.0 \%$ of 1-6-month-old cats and $19.3 \%$ of cats aged 7-12 months had antibodies against $B$. quintana, suggesting that seroconversion for $B$. quintana antigen occurred earlier in life than seroconversion for $B$. henselae antigen. 
Table 2. Prevalence of Bartonella-specific IgG antibodies in sera from pet cats at different ages*

\begin{tabular}{|c|c|c|c|c|c|c|}
\hline \multirow[b]{2}{*}{ Antigen } & \multicolumn{6}{|c|}{ Number $(\%)$ of positive sera from cats aged } \\
\hline & $\begin{array}{l}1-6 \text { months } \\
(\mathrm{n}=23)\end{array}$ & $\begin{array}{l}7-12 \text { months } \\
(\mathrm{n}=88)\end{array}$ & $\begin{array}{l}1-2 \text { years } \\
(n=78)\end{array}$ & $\begin{array}{c}2-5 \text { years } \\
(n=98)\end{array}$ & $\begin{array}{c}6-10 \text { years } \\
(n=85)\end{array}$ & $\begin{array}{c}>10 \text { years } \\
(n=54)\end{array}$ \\
\hline B. quintana & $3(13.0)$ & $17(19.3)$ & $17(21.8)$ & $14(14.3)$ & $14(16.5)$ & $8(14.8)$ \\
\hline B. henselae Marseille & $0(0)$ & $5(5.7)$ & $4(5.1)$ & $4(4.1)$ & $8(9.4)$ & $4(7.4)$ \\
\hline B. henselae Houston-1 & $0(0)$ & $5(5.7)$ & $6(7.7)$ & $5(5.1)$ & $7(8.2)$ & $5(9.3)$ \\
\hline
\end{tabular}

*Prevalence of $B$. henselae-specific IgG antibodies in sera of cats was determined by IFA.

Whereas $16.8 \%$ of cats from northern Germany had $B$. quintana-specific IgG serum antibodies at a titre of $\geqslant 50$, only $8.0 \%$ of cats from southern Germany had positive $B$. quintana-specific antibody titres $(p=0.003$; Fig. 3). The higher seroprevalence in cats from northern Germany coincided with slightly higher rainfall in northern Germany compared with southern Germany (not shown). Moreover, the average temperature was slightly higher in southern Germany. The other epidemiological factors recorded including age, breed, sex, environment, hunting behaviour and $T$. gondii-specific serum antibody prevalence had no impact on Bartonella-specific IgG antibody prevalence in cat sera.

It is well known that the IFA is not specific for a particular Bartonella sp. In fact, considerable crossreactivity to either of the antigens is found in sera from patients with $B$. henselae or $B$. quintana infection $[37,43]$. Similarly, the results of the present study suggest considerable cross-reactivity between the two bartonella antigens in cat sera. Conversely, many of the sera revealed a differential reactivity with either $B$. henselae or $B$. quintana, respectively (data not shown). Thus, while five sera were shown to have anti- $B$. henselae IgG titres of 100 , of these sera were negative when $B$. quintana antigen was used. Likewise, 14 sera showed significant anti- $B$. quintana antibody titres of 200 and 400, respectively, but were negative against $B$.

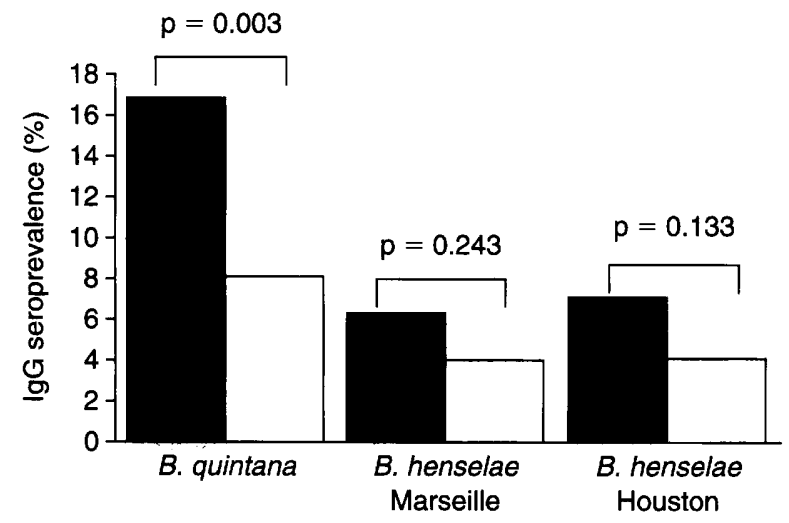

Fig. 3. Prevalence of anti- $B$, quintana, anti- $B$. henselae Houston strain and anti- $B$. henselae Marseille strain antibodies in sera of 200 cats from southern Germany ( $\square$ ) and 513 cats from northern Germany ( $\square$ ) as revealed by IFA assay. Sera with a titre $\geqslant 50$ were considered positive. henselae. Moreover, single sera were preferentially reactive with $B$. henselae Houston strain when compared with $B$. henselae Marseille strain, and vice versa.

Immunoblot analysis was performed on 30 cat sera with $B$. henselae antigens, and revealed a marked reactivity with protein bands with a $\mathrm{M}_{\mathrm{r}}$ in the range $13-80 \mathrm{kDa}$. A representative immunoblot analysis of sera with negative or positive anti- $B$. henselae IFA titres is depicted in Fig. 4a. Comparison of $B$. henselae IFA-positive and IFA-negative sera applied to immunoblot analysis with $B$. henselae revealed that IFApositive sera more frequently $(p<0.05)$ recognised bands at $80,76,73,65,37,33$ and $15 \mathrm{kDa}$ (Table 3). Moreover, the higher the IFA antibody titre of the sera, the more protein bands were usually recognised.

To examine the specificity of the differential reaction of sera with $B$. quintana and $B$. henselae antigen as revealed by IFA, these sera were applied to immunoblot analysis, including both $B$. henselae and $B$. quintana as antigen. As depicted in Fig. 4b, $B$. quintana IFApositive- $B$. henselae-negative sera showed a marked reactivity with protein bands of both $B$. quintana and $B$. henselae. Although the pattern of recognised protein bands is different for both bacterial species, there was nevertheless considerable variation in the protein patterns recognised by sera with the same IFA titre.

\section{Discussion}

The purpose of this study was to determine the seroprevalence of anti- $B$. henselae antibodies in cats in Germany. Although the natural reservoir of $B$. quintana has not yet been established, $B$. quintana was included as an antigen in the study. Furthermore, as $A$. felis has been claimed as an aetiological agent in catscratch disease, this bacterium was also included in the present study, although the relevance of $A$. felis in catscratch disease remains obscure $[23,24]$.

It has been well established that cats are the natural reservoir of $B$. henselae [29-31]. In particular, young cats may have $B$. henselae bacteraemia for varying periods without developing clinical signs of disease $[29,30,40]$. In fact, experimental infection of cats with $B$. henselae causes bacteraemia persisting for up to 32 
a

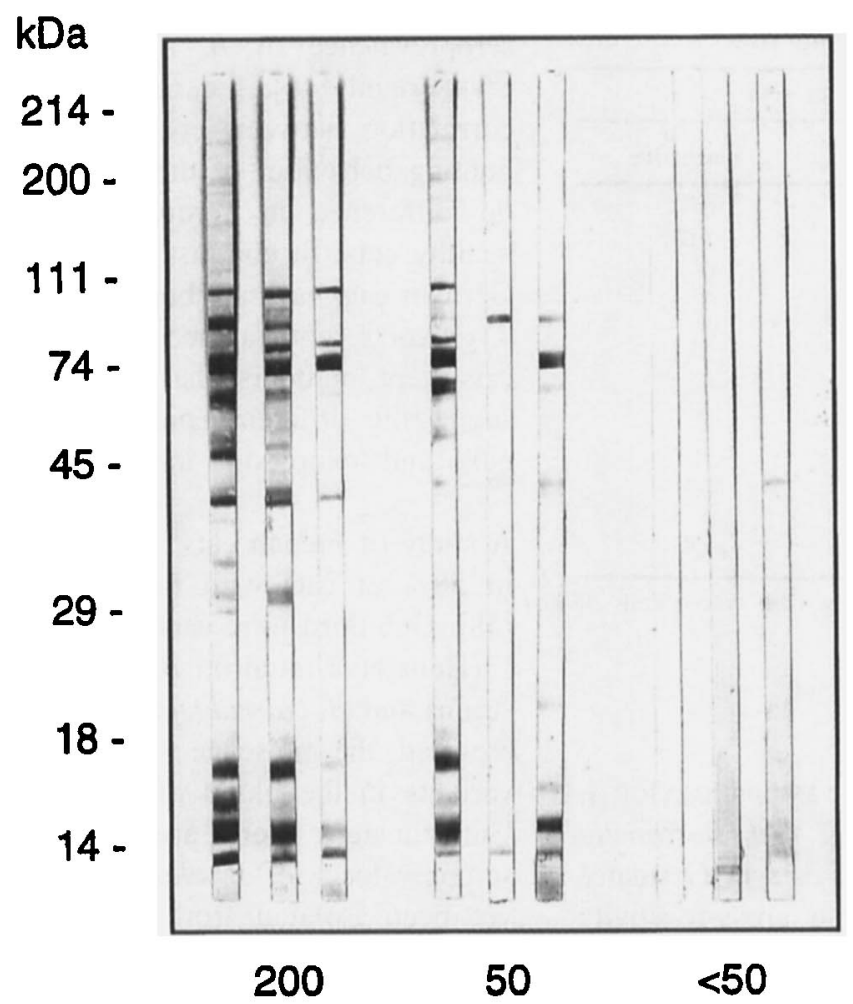

b

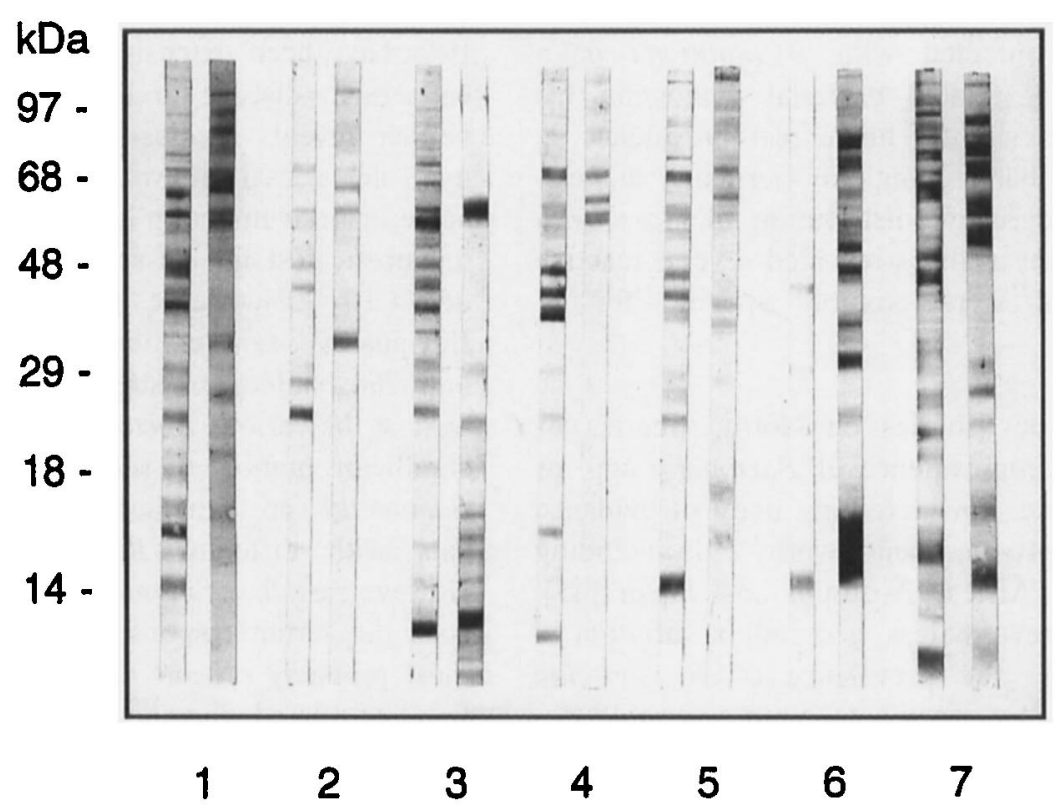

Fig. 4. (a) Immunoblot reactivities of whole cells of $B$. henselae with various IFA-negative or IFA-positive sera. Lanes 1-3, sera from cats with IFA titre of $200 ; 4-6$, sera from cats with IFA titres of 50; 7-9, sera from cats with a negative IFA titre. (b) Immunoblot reactivities of whole cells of $B$. quintana (left lanes) and B. henselae (right lanes) with various IFA (B. quintana)-positive sera (titres 200-400).

weeks [44]. Transmission of $B$. henselae from cats to man probably occurs directly via bites and scratches as well as via cat fleas [30]. Therefore, contact with cats, the presence of cat fleas, as well as childhood are, in addition to immunosuppression, the most important epidemiological risk factors for $B$. henselae infection in man $[29,30,36]$. On the other hand, a recent study demonstrated that the seroprevalence of IgG antibodies to $B$. henselae is similar in cat owners and controls. Thus, $c .20 \%$ of sera in both controls and cat owners contained antibody levels of $\geqslant 64$ [38]. Several studies revealed an overall seroprevalence of $B$. henselae in man between 0 and $26 \%[26-28,37,39]$.

The most salient findings of the present study are as follows. (i) In all, $6-15 \%$ of sera contained anti- 
Table 3. Anti-B. henselae IgG reactivity of sera from pet cats revealed by immunoblotting and IFA

\begin{tabular}{lcc}
\hline & \multicolumn{2}{c}{ Percent of sera } \\
\cline { 2 - 3 } Reactive band & IFA-positive* & IFA-negative \\
\hline 90 & 12.5 & 0 \\
80 & $75.0^{\dagger}$ & $25.0^{\dagger}$ \\
76 & $43.8^{\dagger}$ & $0^{\dagger}$ \\
73 & $68.8^{\dagger}$ & $0^{\dagger}$ \\
65 & $43.8^{\dagger}$ & $0^{\dagger}$ \\
48 & 68.8 & 37.5 \\
40 & 56.3 & 37.5 \\
37 & $37.5^{\dagger}$ & $0^{\dagger}$ \\
33 & 18.8 & 0 \\
30 & 31.3 & 12.5 \\
15 & 31.3 & 0 \\
13 & 25.0 & 12.5 \\
\hline
\end{tabular}

Sera were applied to IFA and immunoblotting with whole cells of $B$. henselae as antigen.

${ }^{*}$ IFA titres $>50$ were considered positive. ${ }_{\mathrm{p}}<0.05$.

Bartonella IgG antibodies, but none was positive for $A$. felis as revealed by IFA, suggesting that Bartonella spp. but not $A$. felis are common in cats in Germany. (ii) Although there was considerable cross-reactivity between the two bartonella antigens used, several sera had $B$. henselae- but not $B$. quintana-specific antibodies, and vice versa. Although it is yet quite speculative, these data suggest that at least single cats might have been infected with $B$. quintana or a serologically closely related bacterial pathogen. (iii) The study found a slightly higher seroprevalence in northern Germany than in southern Germany, suggesting a different geographic distribution of Bartonella spp. (iv) Immunoblot analysis revealed several reactive protein bands that were possibly specific for $B$. henselae.

In line with previous studies on North America or European cats, a seroprevalence of Bartonella spp. of c. $6-15 \%$ was found. An increasing body of evidence suggests that $B$. henselae occurs world-wide including the USA, Europe, Africa, Australia and Japan [45], although there is, nevertheless, geographic variation in seroprevalence, e.g., the prevalence of $B$. henselae antibodies in North American cats is more variable (5$55 \%$; overall incidence $27.9 \%$ ) depending mainly on the geographic distribution [32]. Thus, cats living in warm and humid areas showed a higher seroprevalence than cats in dry or cold regions. In California, $81 \%$ of cats were seropositive for $B$. henselae and $39.5 \%$ had bacteraemia [29]. The authors of these studies claimed that the varying seroprevalence might reflect the different frequency of potential arthropod vectors. Likewise, the results of the present study suggest a geographic impact on the prevalence of bartonella infections in cats, although it is not yet clear whether the slightly different humidity and temperature in northern and southern Germany may account for these results. Unfortunately there were no data available on the presence of possible vectors such as cat fleas in the present study.
In keeping with these data, a recent study revealed a seroprevalence of $B$. henselae of $8.3 \%$ in cats in Switzerland [46], but the authors did not observe a correlation between positive titre and sex, breed or hunting behaviour of the cats. Furthermore, there was no difference in seroprevalence between sick and healthy cats. In contrast to Bartonella spp. c. $50 \%$ of German cats have antibodies against $T$. gondii, and the $T$. gondii seroprevalence is higher in older cats and in cats kept outdoors that frequently go hunting [47], suggesting different epidemiological factors in bartonella and toxoplasma infections in cats.

A study of French cats revealed positive blood culture in $56 \%$ of cats with three different Bartonella spp. [48]. One-third were each positive for $B$. henselae type I (Houston-1 strain), B. henselae type II ('BA-TF' strain) and $B$. clarridgeiae. In Germany, a recent study reported the presence of two different $B$. henselae variants in the blood of $13 \%$ of domestic cats [40]. Unfortunately there are no data available on the seroprevalence of $B$. clarridgeiae. B. quintana has not yet been isolated from cats. There is accumulating evidence that man may be the only reservoir for this pathogen and that it is most probably transmitted by lice $[1-3]$.

IFAs have been extensively evaluated for diagnosis of cat-scratch disease in man. However, the IFA assay neither reveals species-specific antibody responses in man, nor does it allow a clear differentiation between acute or prior infection [37, 43, 49]. Moreover, IFA as a diagnostic test for cat-scratch disease in man may not detect $10-30 \%$ of cases $[3,49]$. In the present study 14 IFA-positive sera exhibited equal antibody titres for both Bartonella spp., suggesting cross-reactivity of sera against the various Bartonella spp. On the other hand a significant number of sera had different titres for both Bartonella spp. Whether this is due to co-infection of cats with different Bartonella spp. is not clear. However, as $B$. quintana has never been isolated from cats, the serum responses of cats against $B$. quintana most probably reflects cross-reactivity against $B$. henselae or related Bartonella spp. such as $B$. clarridgeiae rather than actual infection with $B$. quintana. However, a recent case report argues against this possibility as the authors observed no significant cross-reactive serum antibody response against $B$. quintana in a cat and a patient with $B$. clarridgeiae infection [22]. On the other hand, cross-reactions of bartonella-specific antibodies with other bacterial species, including Chlamydia and Coxiella spp., may occur [3] and this possibility cannot be excluded in the present study.

Nevertheless, as observed in the present study, there might be strain- or serotype-specific antibody responses [8]. A French study demonstrated significantly higher and more frequent positive $B$. henselae-specific antibodies in sera from human patients when they used a European isolate (Marseille strain) of $B$. henselae than 
with an American strain (Houston-1) [50]. Furthermore, there is evidence that the presence or absence of pili on the bacterial surfaces of these strains might account for these differences, and that phase variation in antigen expression paralleled by transition from rough to smooth phenotypes of Bartonella may account for misleading results in serological tests [2].

Immunoblot analysis revealed a broad spectrum of protein bands recognised by cat sera when whole cells of $B$. quintana or $B$. henselae were used as antigen. Protein bands at $80,73,65,37,33$ and $15 \mathrm{kDa}$ were recognised more frequently by IFA-positive sera than by IFA-negative sera, suggesting that certain protein bands are dominant antigens and may be $B$. henselaespecific. However, to date, there are no recombinant antigens available which would make immunoblot analysis much more sophisticated.

This study suggests that $B$. henselae is common in cats in Germany, although there may be geographic variations, and that possibly $B$. quintana-related pathogens (but not $A$. felis) may occur in cats. The seroprevalence of $B$. clarridgeiae remains to be investigated.

We thank Dr Fischer, Schweinfurt/Niederwerrn, for providing cat sera, Siglinde Mathes for expert technical assistance and Rolf Meyer, Institut für Biometrie und Epidemiologie, Tierärztliche Hochschule Hannover, for statistical analysis. Meteorological data were kindly provided by Deutscher Wetterdienst, Munich, Germany.

\section{References}

1. Anderson B, Neuman MA. Bartonella spp. as emerging human pathogens. Clin Microbiol Rev 1997; 10: 203-219.

2. Maurin M, Raoult D. Bartonella infections: diagnostic and management issues. Curr Opin Infect Dis 1998; 11: 189-193.

3. Maurin M, Birtles R, Raoult D. Current knowledge of Bartonella species. Eur J Clin Microbiol Infect Dis 1997; 16: $487-506$.

4. Gray GC, Johnson AA, Thornton SA et al. An epidemic of Oroya fever in the Peruvian Andes. Am J Trop Med Hyg 1990; 42: $215-221$.

5. Matteelli A, Castelli F, Spinetti A, Bonetti F, Graifenberghi S, Carosi G. Verruga peruana in an Italian traveler from Peru. $A m$ $J$ Trop Med Hyg 1994; 50: 143-144.

6. Daly JS, Worthington MG, Brenner DJ et al. Rochalimaea elizabethae sp. nov. isolated from a patient with endocarditis. $J$ Clin Microbiol 1993; 31: 872-881.

7. Drancourt M, Mainardi JL, Brouqui $\mathrm{P}$ et al. Bartonella (Rochalimaea) quintana endocarditis in three homeless men. $N$ Engl J Med 1995; 332: 419-423.

8. Holmes AH, Greenough TC, Balady GJ et al. Bartonella henselae endocarditis in an immunocompetent adult. Clin Infect Dis 1995; 21: 1004-1007.

9. Jalava J, Kotilainen P, Nikkari $\mathrm{S}$ et al. Use of polymerase chain reaction and DNA sequencing for detection of Bartonella quintana in the aortic valve of a patient with culture-negative infective endocarditis. Clin Infect Dis 1995; 21: 891-896.

10. Raoult D, Drancourt M, Carta A, Gastaut JA. Bartonella (Rochalimaea) quintana isolation in patient with chronic adenopathy, lymphopenia, and a cat. Lancet 1994; 343: 977.

11. Slater LN, Welch DF, Hensel D, Coody DW. A newly recognized fastidious gram-negative pathogen as a cause of fever and bacteremia. $N$ Engl J Med 1990; 323: 1587-1593.

12. Spach DH, Kanter AS, Daniels NA et al. Bartonella (Rochalimaea) species as a cause of apparent "culturenegative" endocarditis. Clin Infect Dis 1995; 20: 1044-1047.

13. Autenrieth IB, Haimerl M. Human diseases - apart from cat- scratch disease, bacillary angiomatosis, and peliosis - and carriership related with Bartonella and Afipia species. In: Schmidt A (ed) Contributions to microbiology. Bartonella and Afipia species emphasizing Bartonella henselae. Basel, Karger. 1998: 63-76.

14. Caniza MA, Granger DL, Wilson $\mathrm{KH}$ et al. Bartonella henselae: etiology of pulmonary nodules in a patient with depressed cell-mediated immunity. Clin Infect Dis 1995; 20: 1505-1511.

15. Jacobs RF, Schutze GE. Bartonella henselae as a cause of prolonged fever and fever of unknown origin in children. Clin $J$ Infect Dis 1998; 26: 80-84.

16. Koehler JE, Quinn FD, Berger TG, LeBoit PE, Tappero JW. Isolation of Rochalimaea species from cutaneous and osseous lesions of bacillary angiomatosis. $N$ Engl $J$ Med 1992; 327: 1625-1631.

17. Kusumanto YH, Veenhoven RH, Bokma JA, Schellekens JF. Two patients with atypical manifestations of cat-scratch disease. Ned Tijdschr Geneeskd 1997; 22: 141-148.

18. Le HH, Palay DA, Anderson B, Steinberg JP. Conjunctival swab to diagnose ocular cat scratch disease. Am J Ophthalmol 1994; 118: 249-250.

19. Schwarztman WA, Patnaik M, Barka NE, Peter JB. Rochalimaea antibodies in HIV-associated neurologic disease. Neurology 1994; 44: 1312-1316.

20. Schwarztman WA, Patnaik M, Angulo FJ, Visscher BR, Miller EN, Peter JB. Bartonella (Rochalimaea) antibodies, dementia, and cat ownership among men infected with human immunodeficiency virus. Clin Infect Dis 1995; 21: 954-959.

21. Kordick DL, Hilyard EJ, Hadfield TL et al. Bartonella clarridgeiae, a newly recognized zoonotic pathogen causing inoculation papules, fever, and lymphadenopathy (cat scratch disease). J Clin Microbiol 1997; 35: 1813-1818.

22. Lawson PA, Collins MD. Description of Bartonella clarridgeiae sp. nov. isolated from the cat of a patient with Bartonella henselae septicemia. Med Microbiol Lett 1996; 5: 64-73.

23. Brenner DJ, Hollis DG, Moss CW et al. Proposal of Afipia gen. nov., with Afipia felis sp. nov. (formerly the cat scratch disease bacillus), Afipia clevelandensis sp. nov. (formerly the Cleveland Clinic Foundation strain), Afipia broomeae sp. nov., and three unnamed genospecies. J Clin Microbiol 1991; 29 2450-2460.

24. English CK, Wear DJ, Margileth AM, Lissner CR, Walsh GP. Cat scratch disease. Isolation and culture of the bacterial agent. JAMA 1988; 259: 1347-1352.

25. Müller HE. Detection of antibodies to Afipia species by the microagglutination test. Eur J Clin Microbiol Infect Dis 1993; 12: $951-954$

26. Patnaik M, Peter JB. Cat scratch disease, Bartonella henselae, and the usefulness of a routine serological testing for Afipia felis. Clin Infect Dis 1995; 21: 1064.

27. Raoult D, Dupont HT, Enea-Mutillod M. Positive predictive value of Rochalimaea henselae antibodies in the diagnosis of cat-scratch disease. Clin Infect Dis 1994; 19: 355.

28. Regnery RL, Olson JG, Perkins BA, Bibb W. Serological response to "Rochalimaea henselae" antigen in suspected catscratch disease. Lancet 1992; 339: 1443-1445.

29. Chomel BB, Abbott RC, Kasten RW et al. Bartonella henselae prevalence in domestic cats in California: risk factors and association between bacteremia and antibody titers. $J$ Clin Microbiol 1995; 33: 2445-2450.

30. Chomel BB, Kasten RW, Floyd-Hawkins K et al. Experimental transmission of Bartonella henselae by the cat flea. J Clin Microbiol 1996; 34: 1952-1956.

31. Koehler JE, Glaser CA, Tappero JW. Rochalomaea henselae infection: a new zoonosis with the domestic cat as reservoir. JAMA 1994; 271: 531-535.

32. Jameson $\mathrm{P}$, Green $\mathrm{C}$, Regnery $\mathrm{R}$ et al. Prevalence of Bartonella henselae antibodies in pet cats throughout regions of North America. J Infect Dis 1995; 172: 1145-1149.

33. Koehler JE, Sanchez MA, Garrido CS et al. Molecular epidemiology of bartonella infections in patients with bacillary angiomatosis-peliosis. $N$ Engl J Med 1997; 337: 1876-1883.

34. Spach DH, Callis KP, Paauw SD et al. Endocarditis caused by Rochalimaea quintana in a patient infected with human immunodeficiency virus. J Clin Microbiol 1993; 31: 692-694.

35. Spach DH, Kanter AS, Dougherty MJ et al. Bartonella (Rochalimaea) quintana bacteremia in inner-city patients with 
chronic alcoholism. $N$ Engl $J$ Med 1995; 332: 424-428.

36. Zangwill KM, Hamilton DH, Perkins BA et al. Cat scratch disease in Connecticut. Epidemiology, risk factors, and evaluation of a new diagnostic test. $N$ Engl J Med 1993; 329: 8-13.

37. Jackson LA, Spach DH, Kippen DA et al. Seroprevalence to Bartonella quintana among patients at a community clinic in downtown Seattle. J Infect Dis 1996; 173: 1023-1026.

38. Rath PM, von Recklinghausen G, Ansorg R. Seroprevalence of immunoglobulin $\mathrm{G}$ antibodies to Bartonella henselae in cat owners. Eur J Clin Microbiol Infect Dis 1997; 16: 326-327.

39. Zbinden R, Höchli M, Nadal D. Intracellular location of Bartonella henselae cocultivated with Vero cells and used for an indirect fluorescent-antibody test. Clin Diagn Lab Immunol 1995; 2: 693-695.

40. Sander A, Bühler C, Pelz K, von Cramm E, Bredt W Detection and identification of two Bartonella henselae variants in domestic cats in Germany. J Clin Microbiol 1997; 35: $584-587$.

41. Schmidt HU, Kaliebe T, Poppinger J, Buhler C, Sander A. Isolation of Bartonella quintana from an HIV-positive patient with bacillary angiomatosis. Eur J Clin Microbiol Infect Dis 1996; 15: 736-741.

42. Autenrieth IB, Schwarzkopf A, Ewald JH, Karch H, Lissner R Bactericidal properties of Campylobacter jejuni-specific immunoglobulin $\mathrm{M}$ antibodies in commercial immunoglobulin preparations. Antimicrob Agents Chemother 1995; 39: 19651969.
43. Dalton MJ, Robinson LE, Cooper J, Regnery RL, Olson JG, Childs JE. Use of bartonella antigens for serological diagnosis of cat-scratch disease at a national reference center. Arch Intern Med 1995; 155: 1670-1676.

44. Guptill L, Slater L, Wu C-C et al. Experimental infection of young specific pathogen-free cats with Bartonella henselae. $J$ Infect Dis 1997; 176: 206-216.

45. Relman DA. Editorial response: are all Bartonella henselae strains created equal? Clin Infect Dis 1998; 26: 1300-1301.

46. Glaus T, Hofmann-Lehmann R, Greene C, Glaus B, Wolfensberger $\mathrm{C}$, Lutz H. Seroprevalence of Bartonella henselae infection and correletion with disease status in cats in Switzerland. J Clin Microbiol 1997; 35: 2883-2885.

47. Simon KGM. Evaluation of diagnostic tests for Toxoplasma gondii infections in cats and sheep. Thesis. Tierärztliche Hochschule, Hannover, Germany, 1995.

48. Heller R, Artois M, Xemar V et al. Prevalence of Bartonella henselae and Bartonella clarridgeiae in stray cats. J Clin Microbiol 1997; 35: 1327-1331.

49. Amerein MP, De Briel DD, Jaulhac B, Meyer P, Monteil $\mathrm{H}$, Piemont Y. Diagnostic value of the indirect immunofluorescence assay in cat scratch disease with Bartonella henselae and Afipia felis antigens. Clin Diagn Lab Immunol 1996; 3: 200-204.

50. Drancourt M, Birtles R, Chaumentin G, Vandenesch F, Etienne J, Raoult D. New serotype of Bartonella henselae in endocarditis and cat-scratch disease. Lancet 1996; 347: $441-$ 443. 